Article

\title{
Foreign Tourists in World Heritage Sites: A Motivation-Based Segmentation
}

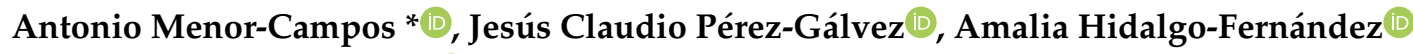 \\ and Tomás López-Guzmán (1)
}

Agrifood Campus of International Excellence ceiA3, University of Córdoba, 14005 Córdoba, Spain; dt1pegaj@uco.es (J.C.P.-G.); ahidalgo@uco.es (A.H.-F.); tomas.lopez@uco.es (T.L.-G.)

* Correspondence: antonio.menor@uco.es; Tel.: +34-95-721-2507

Received: 23 March 2020; Accepted: 15 April 2020; Published: 17 April 2020

check for updates

\begin{abstract}
The inclusion on the lists published by the United Nations Educational, Scientific, and Cultural Organization (UNESCO)—World Heritage Site (WHS), Intangible Cultural Heritage (ICH), and World Heritage Sites in Danger-suggests, first of all, the acknowledgement of something worth protecting and, secondly, an increase in the strength of tourist attraction to the affected destination, especially among specific visitors. The identification and classification of tourists that are seen to be more interested in heritage is the stated aim of this work, based on models already proposed in the scientific literature. For this purpose, a survey was conducted that interviewed a representative sample of international tourists visiting the city of Córdoba. A multi-variant technique of case-cluster was applied. In addition, a discriminant analysis was used to validate the clusters of the cases obtained. For analyzing the differences between the different groups obtained, some non-parametrical statistical procedures were applied. The results obtained allowed for the visualization of a model that shows the empirical evidence regarding the presence of four types of foreign tourists that are considered valid for segmentation in the city of Córdoba as a WHS tourist destination: the alternative tourist, emotional tourist, cultural tourist, and heritage tourist. These results allow public and private managers to design specific strategies to increase visitor satisfaction.
\end{abstract}

Keywords: world heritage sites; heritage tourism; tourist segmentation

\section{Introduction}

Every year, the United Nations Educational, Scientific, and Cultural Organization (UNESCO) publishes three lists corresponding to the World Heritage Site (WHS) entries, the Intangible Cultural Heritage (ICH) entries, and the World Heritage Sites that are in danger. Inclusion on these lists suggests the acknowledgement of a specific place, or an intangible element, as having a value that should be protected for future generations. Additionally, the entry on these lists leads to a strong power of attraction for tourism [1,2]. Therefore, managing to identify the tourists who are interested in heritage, or "heritage tourists," out of all the visitors to these places is one of the most debated aspects in this type of tourism. According to Nguyen and Cheung [3], it is fundamental to determine the motivations for a visit of all the tourists in a WHS- that is to say, whether they visit it because it is a world heritage site.

As a degree of innovation, this research follows a segmentation model of foreign tourists who visit the city of Córdoba, based on two models used in scientific literature in the segmentation of foreign tourists in WHS. From these two models, the first is proposed by McKercher [4] and the second model is the Model of Poria, Butler, and Airey [5]. 


\section{Literature Review}

\subsection{Heritage Tourism}

In the realm of heritage tourism, the academic literature reflects the relationship that exists between the tourists and the artistic and monumental heritage of the destination they visit [3]. This type of tourism is known as heritage tourism and consists of making visits to heritage destinations and having a specific lived experience there. According to Poria, Reichel, and Biran [6], this implies that the visit to WHS areas could be something more than recreational, which is similar to what happens in other destinations, representing a meeting of the visitor with their own cultural heritage. Thus, the visit also involves a way to perceive and to discover the heritage that the place has for each visitor and the meaning of this cultural legacy. On the visitor's behalf, the perception of a destination being part of their heritage is associated with the patterns of the visit [5]. Specifically, those who consider that the place visited is connected to its history and/or culture tend to display a typical behavior that is different to the rest. The understanding of this reasoning is useful for the study of the behavior of tourists and leads to better management of the destinations, as well as planning strategies to enhance this type of tourism by different governments and private businesses.

Cultural tourism, when understood as visiting destinations with an important heritage interest, is not something new. Beginning in the 17th century, it was customary for young English noblemen to undertake journeys of initiation, known as a "Grand Tour," with the aim of discovering landscapes and heritage places in Europe first-hand. This would serve to complete their personal and intellectual education before they entered the social and intellectual elite of the moment upon their return [7]. However, this cultural tourism has become more democratic and generalized with the continuing increase in the flow of people visiting heritage places, with these being the most visited destinations [8] and those listed by UNESCO as World Heritage Sites standing out more than others. Thus, the inclusion on one of these lists indicates the recognition of a worthy universal existence or excellence [9], as well as a label or a mark of a place that should be visited by tourists $[10,11]$. In fact, although the aim of UNESCO in publishing these lists is the search for the preservation and conservation of these places and experiences, in most cases, this also leads to a considerable increase in the number of visitors to these destinations, especially foreign tourists [12]—and, at the same time, an increase in the income resulting from tourism, as well as a change in the business and environmental management of the area [3]. In fact, we can affirm that there is a clear relationship between heritage, sponsored by UNESCO, and tourism [13]. Adie [1] defines this type of tourism in World Heritage Sites as a sub-group within heritage tourism. The academic literature (among others, [14-16]) that has developed the existing relationship between tourism and WHS indicates aspects such as the increase in the number of visits, the socio-economic and environmental management of the area [17], or the satisfaction and motivation of the tourist who visits these places.

In this sense, various research analyzes the association between the heritage legacy and tourism, focusing fundamentally on cultural heritage and the WHS. Thus, in relation to the WHS, the studies completed in Ecuador [18], China [19], Israel [5], Macao [2,14], Portugal [20], and Vietnam [5] can be quoted. Regarding the Intangible Cultural Heritage, there is still very little academic study that has been carried out-something that could be due, in part, to many of the studies regarding cultural heritage and tourism being related to physical places [21]. On the other hand, among the studies that analyze the correlation between tourism and Intangible Cultural Heritage, we can highlight the study regarding the tango by Gómez Schettini, Almirón, and González Bracco [22] as a tourist resource in the city of Buenos Aires; the analysis of the relationship between tourism in the city of Cuenca (Ecuador) and the manufacturing of the Panama hat, listed as an Intangible Cultural Heritage [23], or the work regarding the motivations of tourists who attend the Fiesta de los Patios in Córdoba [24].

In recent decades, the concept of heritage and cultural legacy has followed evolution in two different ways [25]: firstly, by increasing the number of World Heritage Sites. Thus, while initially restricting the inscription of monuments, historical buildings, and archaeological places, the possibility 
has opened to other cultural options, such as gardens, stages, ways of manufacturing, or rural spaces. Secondly, another ensemble of elements has been added that looks for the recognition of different collective identities, such as oral traditions, folklore, or customs that, logically, are part of people's cultural legacies. This means that the relationship between tourism and World Heritage, both tangible and intangible, is a scientific type with an extension that is even greater and that accepts a sustainable cultural and tourist development [26]. Due to the importance of this type of tourism, the scientific literature in this field has increased in recent years [5]. In fact, among the books, we can highlight four: the work of Timothy and Boyd [27], the contributions of Di Giovine [28], the reflections of Timothy [29], or the analysis of Park [30].

Heritage tourism limits the activities that derive from visiting a specific place and the experiences had, regardless of them being produced in natural or cultural environments or being located in rural or urban destinations [3]. This implies that the tourist is looking for a link with their roots and their heritage legacy [15]. Sometimes, the designation as a WHS results in a general recommendation to visit this destination [3,31], as the tourists look for authentic experiences and different places when they travel $[27,30]$.

Currently, there are two main lines of research in the study of heritage tourism [32]: the first is focused on the definition and segmentation of tourism regarding the historical and heritage legacy; the second line analyzes the need for association with the aim of preserving this historical heritage inheritance and the tourist flows. Following Timothy and Boyd [27], we can look into two dilemmas that respond to the question about what heritage tourism is: firstly, the analysis of the presence of visitors in places where an important heritage material is found; secondly, the perception of the visitors in these places as being something that represents their own personal heritage [5]. According to Poria et al. [5], all this leads to the visit of a historical place merely being a recreational experience, where the tourist has the opportunity to visit a place with a recognition of universal excellence or an encounter with a place that is an important part of their own cultural heritage [33].

\subsection{Tourist Segmentation}

In order to correctly manage a tourist destination that is considered a WHS and to design diverse tourist services that address various demands, an appropriate segmentation of the tourists that visit it is essential [34]. Because of this, it is fundamental to identify the diverse nature of heritage tourists, their motivations, their behaviors, and their perceptions [3]. This way, the heritage tourist can be clearly differentiated-or, according to Adie and Hall [35], even the tourist who is mainly attracted by the acknowledgement of the place as a World Heritage Site can be detected and, at the same time, differentiated from other tourists who visit [36].

There are different types of visitors in terms of the segmentation of these in heritage destinations. We can find a complete relationship of the different research carried out in this field in the study published by Chen and Huang [37].

Silberberg [38], on the basis of the interest that the traveler has for visiting a specific place, indicates four different types of tourists:: accidental cultural tourists, adjunct cultural tourists, in part cultural tourists, and greatly cultural tourists. In the segmentation of heritage tourists, we quote McKercher [4], who analyzes two different dimensions. The first is the importance of cultural motivations when the tourist decides to visit a specific destination. The second dimension is the scale and depth of the information that the tourists have regarding this place. Regarding the basis of these two dimensions, five different types are proposed: incidental cultural tourist, casual cultural tourist, serendipitous cultural tourist, sightseeing cultural tourist, and purposeful cultural tourist. This segmentation model for tourists has been applied to different research, such as that of McKercher and du Cros [39], Nguyen and Cheung [3], and Chen and Huang [37].

Poria et al. [5] conducted a segmentation of the tourists based on the perception that they have their own heritage with the relationship between the tourist and the destination. Thus, they differentiate three types of visitors: first, those tourists who visit places that are not related to their true heritage; 
second, those tourists who seek a deeper knowledge of their heritage; and third, tourists who do not consider themselves part of the heritage they are visiting.

Ramires et al. [20] segment tourists according to two attributes of the destination, such as culture and leisure and economic value. They establish three groups: conventional, spontaneous, and absorptive. Following McKercher's model [4], Chen and Huang [37] segment the tourists on the basis of the importance of culture and the importance of the cultural experience.

The academic literature has developed various provisions for the segmentation. One of the most common research techniques in tourism is factor-cluster analysis [40,41]. However, numerous critics have developed positions against this approach due to the lack of original information, the abstract exegesis, or incorrect theories [42-44]. This research uses the segmentation approach recommended by Dolnicar [42], which is based on the continuous cluster of original scores. By employing the original scores, a more precise segmentation is obtained due to the ability to retain a greater degree of original information [44-46].

In line with the scientific literature, the hypotheses to compare in this research are the following:

Hypothesis 1 (H1). Some tourists have emotional experiences that lead them to feel, more than consider, the place they visit.

Hypothesis 2 (H2). When addressing the emotional experiences and the cultural interest of a WHS destination, there are different types of visitors.

\subsection{Tourist Motivations}

Motivation influences the choices made, and it is considered to be one of the main impulses of the tourist when it comes to planning their journey. The reasons why an individual chooses a destination and travels there may be varied, as may be the case with Córdoba. If we analyze the scientific literature regarding the motivations as to why a person requests a specific product or service, it is observed that it is to do with a variable that is subject to changes in the environment, as well as in the variations of the behavior that they produce in society itself. Accordingly, motivation is a dynamic process that the consumer modifies in relation to their experience, status, or age [47].

Tourists display different types of motivations when they decide to travel, and culture is one of the main ones [8]. At the same time, the specific destination has to be analyzed, as there is a wide range of places, as well as variables, that affects each one of them [12]. Therefore, strong competition is created among the destinations with an important heritage legacy to attract tourists, especially those who come from abroad [15,48]. According to Abuamoud, Libbin, Green, and Alrousan [49], the demand for these cultural destinations is influenced by the services provided by public managers and private businesses, as well as due to the complicity of the local community in the promotion of tourism in these areas. In fact, when analyzing the influence of a WHS entry on tourists, Mariani and Guizzardi [11] conclude that, in the assessment of a destination, it is required to not only have a UNESCO acknowledgement, but also a positive assessment on the visitors' behalf that basically depends on the managers of the destination.

In order to analyze the motivations of tourists, there are three different referential frameworks [50]: first, Iso-Ahola's escape seeking dichotomy [51]; second, the Travel Career Ladder [52]; and third, the push-pull model [53,54]. The push-pull model is the one that is most widely used in scientific literature [55] and it is the one most commonly used in the classification of literature that addresses the motivations of the tourists [16]. Therefore, the push factors are the factors that influence the decision to go on a journey. For their part, pull factors influence the choice of a specific destination to visit. As a result, the push factors are considered as precedents to pull factors [56].

The identification of tourists' motivations, their level of satisfaction, their assessments, and their degree of loyalty is basic in order to perform the correct sustainable management of the destinations. Therefore, a definition of the corresponding strategies on behalf of the public managers, as well as 
the private businesses, is necessary. Thus, following Vong and Ung [14], four motivational factors are provided in relation to the management of heritage tourism: first, the history and culture of the place; second, the facilities and the services in these areas; third, the interpretation of the heritage; and fourth, the attractions that are offered to tourists. For their part, Vareiro, Freitas, Remoaldo, and Cadima [57] collect the motivations into four different components: historical references and accessibility, shopping and entertainment, convenience, and efficiency. For their part, Io [2] indicates the importance of ICH for foreign tourists and identifies the attributes in five dimensions to analyze the experience of the traveler in the destination: authenticity and nostalgia, handicrafts, consumption, enjoyment, and cultural meaning.

However, in specific destinations, no relationship between the historical heritage of the place and the cultural identity of the tourist has been detected. This implies that the people found in this place are mere visitors [36]. As such, it is necessary, on the part of public managers and private businesses, to correctly interpret the transcultural context of these places [36]. This involves, on the part of the public managers, developing reinforcement in these places for the visitor's understanding of the WHS [5]. This reinforcement should be greater when it deals with foreign tourists that also have a different culture [9].

Nguyen and Cheung [3] differentiate between tourist motivations and heritage motivations. In the first group of motivations, entertainment and the search for knowledge are indicated. Meanwhile, for the second group, finding personal wealth, learning about the place, and discovering the culture of the place are specified. Romao, Neuts, Nijkamp, and Van Leeuwen [58] group the motivations into three large dimensions: culture, business, and entertainment. For their part, Almeida-Santana and Moreno-Gil [59] collected the different motivations into the following groups: leisure and rest, knowledge and culture, prestige and social relationships, sports, entertainment, and meeting new people.

\subsection{Satisfaction with the Visit}

In order to fulfil the aim of the place visited and to make the journey remain memorable for the person, an essential requirement is fulfilling the plain satisfaction of the tourist. Accordingly, this satisfaction is the background for loyalty to the destination $[56,60]$. The satisfaction can be defined as the entire assessment that the service client receives in comparison with the service expected [61]. In this definition, the cognitive component of satisfaction takes precedence but, at the same time, it is essential to indicate that the satisfaction variable also has a strong emotional component [62]. Every tourist destination should adopt, among other measures, systematic control for the levels of satisfaction and use this information as part of the assessment criteria [63]. The satisfaction of the tourist is important for many reasons. First of all, it allows us to detect to what extent the attributes and components of the destinations may be perceived and study the nature that is transferred by means of the image of the destination with the aim of favoring the maintenance of the attributes or the components that it deals with. Secondly, satisfaction is one of the most important backgrounds of the future behavior or loyalty of the visitor [64-66]. Satisfaction with the destination is directly related to the motivations for travelling [58], although the socio-demographic profile of the visitor is also a key element in determining satisfaction with the trip [58].

In line with the scientific literature, the hypothesis to compare is the following:

Hypothesis 3 (H3). Motivation affects the satisfaction of the tourist experience, with a higher level of satisfaction among tourists with a greater cultural motivation in a WHS destination.

\section{Materials and Methods}

Figure 1 shows the flow chart of the investigation, which is shown below. 


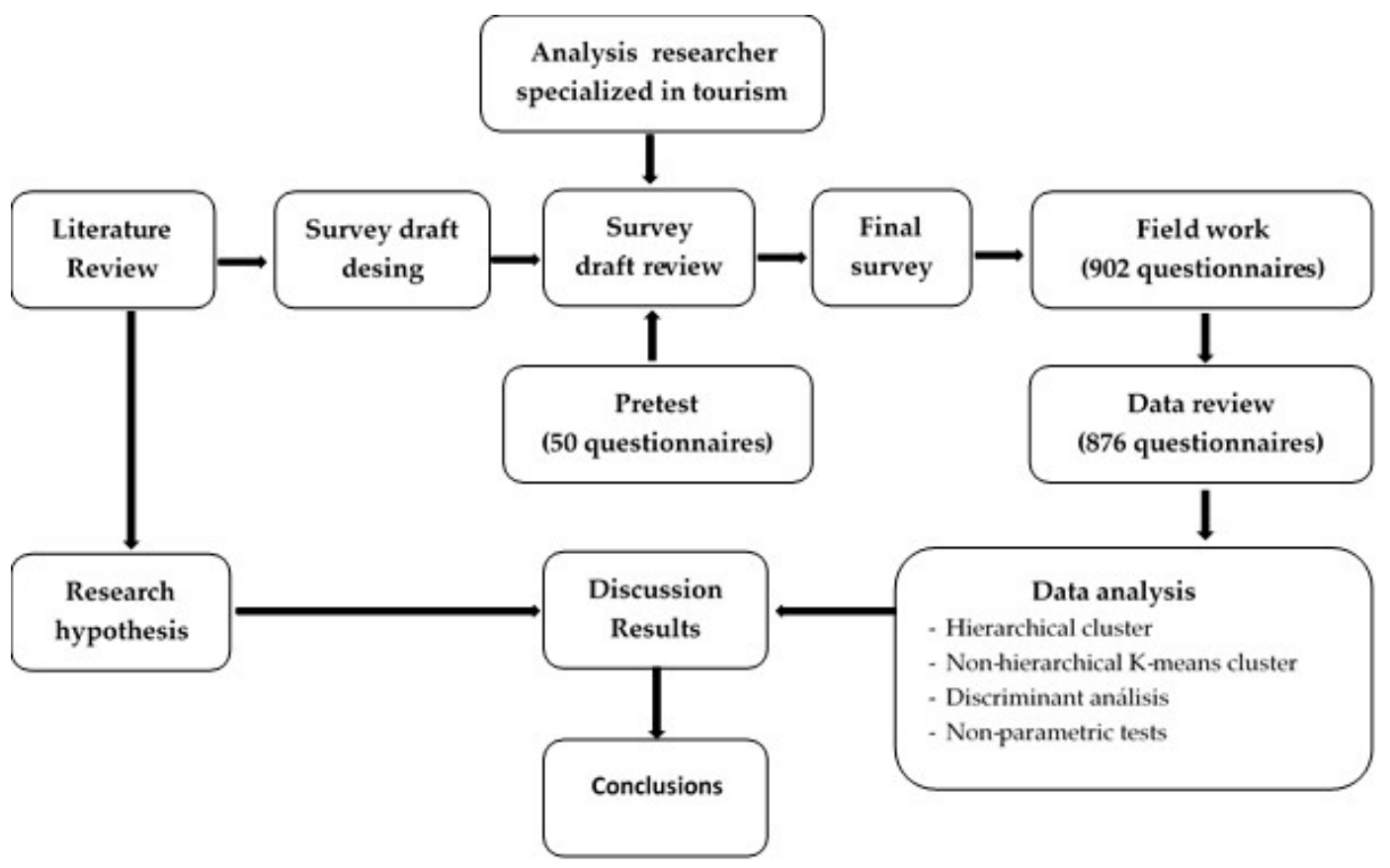

Figure 1. The flow chart of the investigation. (Source: Own elaboration).

\subsection{Questionnaire and Procedure}

This research is based on the results obtained from field research that consisted of handing out a structured questionnaire to a representative sample of foreign tourists who visited the city of Córdoba. From the different options considered for collecting the information, a design using a closed questionnaire was chosen so as to be self-administered. The items were formulated on the basis of different previous research $[4,5,8,15,67-69]$ with the aim of guaranteeing the validity of the questionnaire. The draft of the survey began with an initial ensemble of items, which were subjected to a refinement process in three different stages: first, a researcher specializing in tourism analyzed the proposed items; second, the resulting questionnaire was reviewed by the various people responsible for tourist management in the city of Córdoba; and third, a pre-test was performed on 50 foreign tourists. During the refinement stage, it was detected that some questions were not easily understood by the respondents, leading to their correction. As such, the definitive field work was completed once the questions had been assessed and the viability of the questionnaire had been determined, searching for maximum clarity in the questions formulated and the best adjustment of the answers to achieve the aims set out in the research, as well as the best assessment possible, and avoiding an excessive interview length for the visitors surveyed. Therefore, the final version of the questionnaire was obtained. The questionnaires were carried out in different points of the historic center of the city with the condition that the tourist surveyed had spent time in the destination and, as such, could give an informed opinion $[8,15]$.

The survey was divided into three large blocks. The first block detailed the characteristics of the journey or the visit. This block analyzed the number of previous visits to the city of Córdoba, the length of the stay, the type of establishment used to stay overnight, and the means by which they discovered the city. The second block focused on the reasons for visiting Córdoba, the emotional perceptions of those surveyed regarding the historical heritage and the monuments visited, the assessment of the main attributes related to the visit, the level of satisfaction achieved in terms of the experience, and the attitude of loyalty. In this block, we measured the three variables that we especially needed for the research: both cultural and non-cultural reasons to visit the city, and the relevance of the cultural experience for the visitors. The third block contained the socio-demographic profile of the visitors, such as age, sex, economic level, profession, or degree of education. 
The questions of the first block of the questionnaire and the majority of the items related to the socio-demographic profile of the tourist, which were collected in the third block of the survey, were closed. The second part of the questionnaire was formulated into one five-point Likert scale, with 1 being very little and 5 being a lot. The questions were formulated in positive and negative terms with the aim of avoiding doubt. The questionnaires were handed out in three languages: Spanish, French, and English. Every one of the people surveyed chose the language of the survey.

Out of the 902 people surveyed, 876 were valid. They were completed between the months of December 2014 and December 2015. The questions were completed in different places of the historic center of Córdoba, on different days and at different times in order to collect the widest range of people and situations possible. Convenience sampling was used, which is commonly used in this type of research, where the tourists are available to be surveyed in a specific space and time [70]. It was not stratified by sex, age, education, nationality, or any other variable, as there were no previous studies to support this stratification. The rejection rate for the questionnaire was low and not significant in terms of any variable. The length of the survey was no longer than $10 \mathrm{~min}$.

\subsection{Sampling and Sampling Error}

The specific frame of this research was the foreign tourist who visited the city of Córdoba, regardless of whether they stayed overnight in the city or not, or if they visited other places in the province or in Andalusia. It was difficult to determine the total number of foreign visitors to the city of Córdoba due to the lack of disaggregated data. The data provided by the Regional Government of Andalusia and the Instituto Nacional de Estadística (INE, Madrid-Spain, "Spanish National Institute of Statistics") referred to overnight stays in hotels and, as such, did not consider the arrival of people on day trips or those staying in any other type of establishment, such as tourist apartments or in the houses of family and/or friends. However, in this research, we considered the number of foreign tourists staying in hotels in the city of Córdoba to be the study universe. According to the INE [71], this number was 437,089 foreign tourists in the year 2014. Therefore, with an approximate nature, if probability random sampling had been used in this research, the sampling error for a level of confidence of $95 \%$ would be $\pm 3.31 \%$.

\subsection{Data Analysis}

The tabulation and the statistical analysis of the data were completed using the SPSS v. 25 computer program. Therefore, the multi-variant technique of case clusters (both hierarchical conglomerates and non-hierarchical conglomerates and K-means) was applied with the aim of analyzing the similarity among the people surveyed on the basis of three indicative variables: first, the cultural motives for visiting the city of Córdoba; second, the non-cultural motives in the decision to visit the city of Córdoba; and third, the importance of the cultural experience on the part of the tourist in this destination. Additionally, the technique for discriminant analysis in order to validate the clusters of cases obtained in the analysis of conglomerates was used. Other statistical techniques, such as Factorial Analysis of Variance or Logit, were not considered adequate in this investigation. From the groups or segments obtained, statistics and measures of association that provided the information required to study the possible association patterns among the variables from a table of bi-dimensional contingencies were applied. Similarly, non-parametric statistical procedures were used (Kruskal-Wallis' $\mathrm{H}$ and Mann-Whitney's U statistics) with the aim of analyzing the differences among the different groups obtained in the sample.

\section{Results}

\subsection{Emotional and Motivational Perception of the Visit}

This research was based on the segmentation of foreign tourists who visited the city of Córdoba, using the models of McKercher [4] and Poria et al. [5] as a basis. Therefore, an assessment of the 
emotional and motivational perception of the visit to the city of Córdoba was requested from the foreign tourists surveyed using a Likert scale of five points, with 1 being little and 5 being a lot. The different items used are collected in Table 1.

Table 1. Emotional and motivational perceptions of the visit.

\begin{tabular}{|c|c|c|}
\hline Emotional & erception of the historical heritage visited & Mean \\
\hline \multirow{4}{*}{$\begin{array}{l}\text { Cronbach's Alpha (0.662) } \\
\text { Mean (3.89) }\end{array}$} & $\begin{array}{l}\text { Visiting the historical heritage of the city has contributed to } \\
\text { my education }\end{array}$ & 4.19 \\
\hline & Visiting the historical heritage of the city has excited me & 4.05 \\
\hline & During the visit, I felt like part of the heritage & 3.08 \\
\hline & $\begin{array}{l}\text { The visit to the historical heritage of the city made me } \\
\text { feel good }\end{array}$ & 4.25 \\
\hline \multicolumn{2}{|r|}{ Cultural motivations (Pull Factors) } & Mean \\
\hline \multirow{3}{*}{$\begin{array}{l}\text { Cronbach's Alpha (0.643) } \\
\text { Mean (3.15) }\end{array}$} & Discover its historical and monumental wealth & 3.99 \\
\hline & Attend cultural events: exhibitions, festivals, concerts, etc. & 2.09 \\
\hline & Taste the gastronomy & 3.36 \\
\hline \multicolumn{2}{|c|}{ Non-cultural motivations (Push Factors) } & Mean \\
\hline \multirow{5}{*}{$\begin{array}{l}\text { Cronbach's Alpha (0.706) } \\
\text { Mean (3.42) }\end{array}$} & Disconnect from daily life & 3.43 \\
\hline & The desire to discover new places & 4.13 \\
\hline & The fame and tourist reputation of the city & 3.78 \\
\hline & It is one more visit of my tourist itinerary & 2.93 \\
\hline & It is a tourist destination that I can afford & 2.80 \\
\hline
\end{tabular}

Source: Own elaboration.

Therefore, following the push-pull model, a questionnaire with different items that dealt with collecting the most common and relevant travel motivations was analyzed in previous research [8,67-69] and adapted to consider the specific characteristics of this tourist destination and the visitors. The motives impacting tourist behavior were included in two large blocks [54]: firstly, push factors, which were connected with internal and emotional aspects, such as, resting and relaxing or discovering new places to spend more time with family and/or friends, among others; secondly, pull factors, which were related to external, cognitive, or situation aspects, such as the cultural and/or natural settings, gastronomy, or recreational infrastructure.

Cronbach's alpha coefficient [72] of the final scale reached a value of 0.734 , following the existence of a worthy internal consistency among the elements of the scale. This coefficient reached positive values between zero and one, where zero indicated the complete absence of internal consistency, and one the total redundancy of these different items. Morales, Urosa, and Blanco [73] considered a value of 0.5 to be the minimum if it was basic research, as this research would be around 0.85 if it was diagnostic research. The critical level (p) associated with Friedman's $\chi^{2}$ statistical (2311.432) of the analysis which was used to compare whether the null hypothesis of all the elements of the scale had the same mean, is less than 0.001 . Therefore, it rejected the hypothesis that the means of the elements were the same.

\subsection{Tourist Segmentation}

In order to perform the tourist segmentation, the academic literature recommended a method of hierarchical cluster followed by a non-hierarchical method [74]. In our study, two hierarchical algorithms - the complete link and the Ward method—were initially applied using Euclidian squared distances to identify the possible data clusters. Both techniques prevailed in the scientific literature that studied tourist market segmentation [46]. The aim of this segmentation was to identify groups, clusters, or segments of tourists that were very similar in terms of emotional and lived perceptions derived from the visit to monumental heritage and their motivations to visit the destination. An examination of the chronograms of the resulting conglomeration and the dendrograms suggested two or four cluster solutions (Figure 2). 

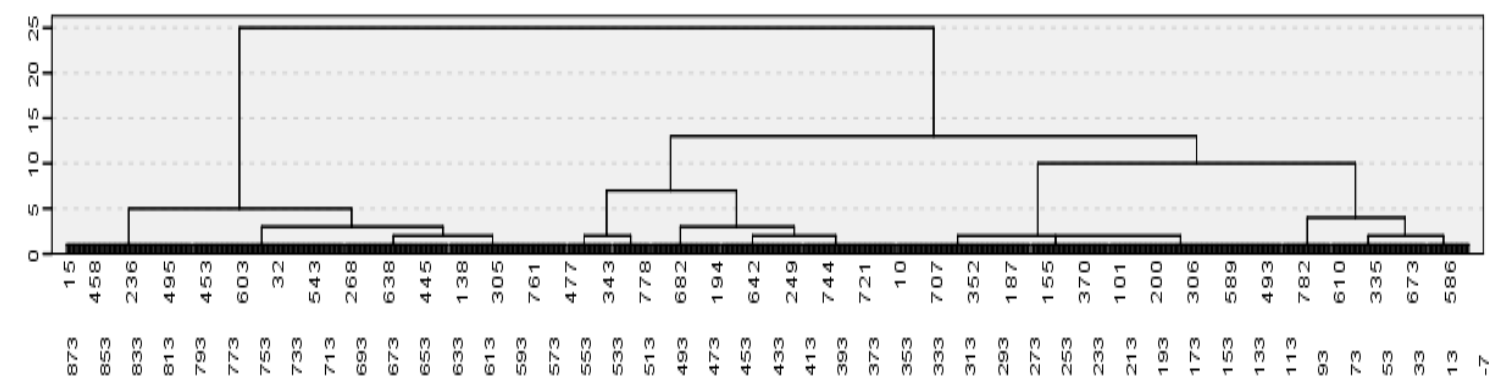

Figure 2. Dendrogram Ward link. Source: Own elaboration.

By enacting a more detailed examination of the group assignment and the size of the group and the later analysis using a non-hierarchical K-means cluster algorithm, it confirmed that the most appropriate solution for tourist segmentation in this research was using the four clusters.

Table 2 showed the characterization of the segments or clusters from the means of the items that intended to measure the emotional perception of the tourist and the motivations for visiting the destination. Kruskal-Wallis' H statistical [75] allowed the comparison that the compared means were not the same among the different clusters, but they did not allow the identification of where the detected differences were found. In order to know which mean differed from the other, Mann-Whitney's U statistical test [76] was used. The names of the four tourist segments were the following: (1) alternative tourist, (2) emotional tourist, (3) cultural tourist, and (4) heritage tourist.

Table 2. Characterization of the emotional and motivational perception of the visit by segments.

\begin{tabular}{ccccccc}
\hline Variables & \multicolumn{3}{c}{ Tourist Segments } & \multicolumn{2}{c}{ Kruskal-Wallis H } \\
\cline { 2 - 7 } & $\begin{array}{c}\text { Alternative } \\
\text { (Mean) }\end{array}$ & $\begin{array}{c}\text { Emotional } \\
\text { (Mean) }\end{array}$ & $\begin{array}{c}\text { Cultural } \\
\text { (Mean) }\end{array}$ & $\begin{array}{c}\text { Heritage } \\
\text { (Mean) }\end{array}$ & $\chi^{2}$ & Sig. \\
\hline $\begin{array}{c}\text { Emotional } \\
\text { Perception } \\
\begin{array}{c}\text { Cultural } \\
\text { Motivation }\end{array}\end{array}$ & $2.75\left(^{*}\right)$ & $3.96\left(^{*}\right)$ & $3.49\left(^{*}\right)$ & $4.49\left(^{*}\right)$ & 325.362 & $<0.000$ \\
$\begin{array}{c}\text { Non-Cultural } \\
\text { Motivation }\end{array}$ & $2.07\left(^{*}\right)$ & $2.73\left(^{*}\right)$ & $3.85\left(^{*}\right)$ & $4.25\left(^{*}\right)$ & 568.411 & $<0.000$ \\
\hline
\end{tabular}

$\left.{ }^{*}\right)$ The values show significant differences in three of the four groups of means. To confirm the significant differences among the mean differences, Mann-Whitney's U test was applied. Source: Own elaboration.

The first segment made up $12.1 \%$ of the foreign tourists surveyed. It was named alternative tourist and it consisted of visitors whose cultural motivations did not play a significant role in the process of choosing the destination. In terms of places to visit with an important historical heritage, they had a superficial emotional experience. The second group represented $46.1 \%$ of the sample and was characterized by grouping tourists so that, although cultural interest played a minor role in the decision of visiting the destination, the visit to a place with an important monumental and artistic heritage allowed them to have a deep emotional experience. This cluster was called emotional tourist. The third group consisted of $14.6 \%$ of respondents, for whom obtaining a better knowledge of the artistic and monumental heritage and their own cultural experience were two of the most important reasons to visit the destination. However, at the same time, this type of tourist had a minor emotional experience. This cluster is known as cultural tourist. The fourth segment was characterized by showing a greater emotional link with the heritage visited and an important cultural motivation by the destination. This cluster represented $27.2 \%$ of those surveyed and was named heritage tourist.

The results of the analysis were validated by means of a discriminating analysis in order to know the percentage of subjects that were correctly assigned. Table 3 shows a contingency square among the individuals belonging to each cluster and those that are correctly classified according to this analysis. Though there were four of the individuals (238) of the heritage cluster that the analysis placed among 
the rest of the clusters, the relevant part was that the classification into four groups was valid, as $98.7 \%$ of the individuals were correctly classified.

Table 3. Discriminant analysis synthesis.

\begin{tabular}{cccccc}
\hline & \multicolumn{3}{c}{ Predicted Membership Clusters } & \multirow{2}{*}{ Total } \\
\cline { 2 - 4 } & Alternative & Cultural & Emotional & Heritage & \\
\hline \multicolumn{7}{c}{ Count } \\
\hline Alternative & 105 & 1 & 0 & 0 & 106 \\
Cultural & 3 & 398 & 0 & 3 & 404 \\
Emotional & 0 & 0 & 128 & 0 & 128 \\
Heritage & 0 & 3 & 1 & 234 & 238 \\
\hline \multicolumn{7}{c}{ Percentage } \\
Alternative & $99.1 \%$ & $0.9 \%$ & $0.0 \%$ & $0.0 \%$ & $100 \%$ \\
Cultural & $0.7 \%$ & $98.5 \%$ & $0.0 \%$ & $0.7 \%$ & $100 \%$ \\
Emotional & $0.0 \%$ & $0.0 \%$ & $100.0 \%$ & $0.0 \%$ & $100 \%$ \\
Heritage & $0.0 \%$ & $1.3 \%$ & $0.4 \%$ & $98.3 \%$ & $100 \%$ \\
\hline
\end{tabular}

The results of this research allowed for the support of two of the suggested hypotheses of this research: the first hypothesis—in line with academic literature [5,6,77-79] — that some tourists have experiences that lead them to feel, more than consider, the place they visit $\left(\mathbf{H}_{\mathbf{1}}\right)$; and the second hypothesis that there are different types of tourists regarding the experiences and the cultural motivation for the heritage visited $\left(\mathbf{H}_{\mathbf{2}}\right)[4-6,38]$.

\subsection{Visit Satisfaction}

On a Likert scale of 5 points, with 1 being hardly satisfied and 5 being very satisfied, the average level of satisfaction stated by the foreign tourists surveyed was high (4.20 points). Therefore, six out of every ten people surveyed stated that they were plainly satisfied. In this group, a greater frequency of heritage tourists (79.4\% indicated 5 points) was found. Therefore, referring to the lack of importance of those not satisfied, only $13.1 \%$ of those surveyed showed a score equal to or less than two.

Given that the visitors were satisfied with their visit to the city of Córdoba in the end, this aspect was considered carefully when analyzing the relationship that may exist between the emotional experience and the reasons or motives for attending the destination. This relationship is important for achieving good tourist management and planning. The aim was to determine the extent of the emotional perception and the motivation for visiting the destination in terms of the satisfaction felt by the tourist. The data showed that the emotional experience and the cultural motives discriminated significantly in terms of the degree of satisfaction perceived (Table 4). The correlation indexes, despite not being very high, indicated that when the emotional experience and the presence of cultural-type reasons were higher, the perceived satisfaction by the foreign tourist who visited the city of Córdoba was higher.

Table 4. Emotional experience, motivation, and visit satisfaction.

\begin{tabular}{cccc}
\hline \multirow{2}{*}{ Dimensions } & \multicolumn{2}{c}{ Kruskal Wallis } & Correlation \\
\cline { 2 - 3 } & $\chi^{2}$ & Sig. & \\
\hline Emotional experience & 98.423 & $<0.000$ & $0.33\left(^{* *}\right)$ \\
Cultural motivation & 67.473 & $<0.000$ & $0.26\left(^{* *}\right)$ \\
Non-cultural motivation & 16.006 & $<0.003$ & $0.04\left(^{* *}\right)$ \\
\hline
\end{tabular}

$\left.{ }^{* *}\right)$ Significant correlation for a meaning level of 0.001 (bilateral). Source: Own elaboration. 
The results showed that emotional experience, as well as cultural motivation, were factors that contributed and conditioned tourist satisfaction $\left(\mathbf{H}_{3}\right)$, with this being higher among foreign tourists with a greater emotional perception before the monumental and historic heritage was visited and with a greater cultural motivation - that is to say, by the tourists clustered in the heritage tourist segment (Table 5).

Table 5. Analysis of tourist satisfaction by segments.

\begin{tabular}{ccccccc}
\hline \multirow{2}{*}{ Satisfaction } & \multicolumn{3}{c}{ Segments } & \multicolumn{2}{c}{ Kruskal Wallis } \\
\cline { 2 - 7 } & $\begin{array}{c}\text { Alternative } \\
\text { (Mean) }\end{array}$ & $\begin{array}{c}\text { Emotional } \\
\text { (Mean) }\end{array}$ & $\begin{array}{c}\text { Cultural } \\
\text { (Mean) }\end{array}$ & $\begin{array}{c}\text { Heritage } \\
\text { (Mean) }\end{array}$ & $\chi^{2}$ & Sig. \\
\hline 3.46 & $4.34\left(^{*}\right)$ & 3.79 & $4.56\left(^{*}\right)$ & 65.047 & $<0.000$ \\
\hline
\end{tabular}

${ }^{*}$ ) The values in bold show significant differences in three of the four groups of means. In order to confirm the significant differences among the different means, Mann-Whitney's U test was applied. Source: Own elaboration.

\section{Discussion}

The tourist segmentation in tourist heritage destinations was analyzed in different prior research [4,5,37-39]. Therefore, in all these previous studies, as in this research, the conclusion was reached that the tourists show different attitudes towards the heritage as an interest variable in choosing the destination. On the other hand, the majority of the studies coincide in indicating that, in the segmentation of tourists, one of the groups is very interested in the heritage, while another of the groups shows very little interest. Thus, in the case of tourists who are very interested in heritage, the authors give them many names: greatly cultural tourists [38], absorptive [20], or tourists who visit the place because it is part of their heritage [6]. In this research, a type of tourist known as a heritage tourist was also detected. The opposite happened with the group known in this research as the alternative tourist- that is to say, when the cultural identity of the visitors was not related to the heritage they visited. This type was also detected in previous research under the name of accidental cultural tourists [38] or a casual tourist [39].

In terms of the satisfaction variable, this research supports the results of the previous literature $[58,62,66]$ in the sense that satisfaction is greater in tourists who are more interested in the heritage.

\section{Conclusions}

By being recognized as a World Heritage Site by UNESCO, the place receives a cultural acknowledgement and a commitment to the preservation of the place on the one hand and, on the other hand, it creates an important attraction for the promotion of the destination for a specific type of tourist, and, as such, the need to properly manage this place. The cultural tourist potential of the city of Córdoba means that it is necessary to perform studies that allow for obtaining results and finding keys that are essential when it comes to planning and developing strategies for improvement or tourist promotion. The differentiating plans in the tourist offer go through an exhaustive description of the tourists that visit the city. This not only involves an analysis of the socio-demographic variables, but also an analysis of the perception that the tourist has of the monumental historical heritage visited, as well as their motivations, their interests, or their expectations.

This research consists of a contribution to the existing academic literature regarding the links between the tourist and the historical and monumental heritage they visit and their tourist behavior. Addressing the emotion perceived when visiting the historical and monumental heritage of the destination — following the Poria et al. [5] model—and the greater or lesser cultural motivation in the decision to visit the destination—following the McKercher model [4] —a model is obtained that shows the empirical evidence regarding the presence of four types of foreign tourists who are considered valid to segment in the city of Córdoba as a WHS tourist destination: the alternative tourist, emotional 
tourist, cultural tourist, and heritage tourist. From the four clusters identified, the link with the heritage visited and the cultural motivation by the destination shows a relevant role among the heritage tourists.

In relation to the satisfaction variable, one of the main contributions of this research is stating that the degree of satisfaction towards a WHS is conditioned by the motivations for visiting it. The results support that the cultural dimension contributes to the satisfaction of the destination to a large extent. Similarly, the greater interest translates into significantly different perceptions regarding the tourist attributes of the destination, with cultural resources being valued at a higher extent.

The main practical application of this research is to contribute to the understanding of the characteristics of the different groups of foreign tourists identified and the assessment that they make of the destination with the aim of creating tourist and cultural products that better meet their needs and, at the same time, are compatible with the sustainable management of the historic and monumental heritage. These results may be of interest to both public managers and private companies related to the tourism sector in the city of Córdoba. Accordingly, and with the aim of continuing to improve the value of Córdoba as a cultural destination, it is necessary to establish measures that favor the understanding of the historic and monumental heritage that is visited, with the aim of favoring deep tourist experiences.

The main restriction of this research is that the study is based on demand only, which could lead to difficulty in moving the results to other groups of stakeholders, such as the local community or tourist businesses. For a future line of research, it is recommended to reinforce the research that tourist activity provides from the offered point of view.

Author Contributions: Conceptualization, A.H.-F. and T.L.-G.; Data curation, A.M.-C.; Formal analysis, A.M.-C. and J.C.P.-G.; Investigation, A.H.-F.; Methodology, A.M.-C. and J.C.P.-G.; Project administration, T.L.-G.; Supervision, J.C.P.-G.; Validation, A.H.-F. and T.L.-G.; Writing—original draft, A.H.-F. and T.L.-G.; Writing-review \& editing, A.M.-C. and J.C.P.-G. All authors have read and agreed to the published version of the manuscript.

Funding: This research received no external funding.

Acknowledgments: The authors of this article would like to thank the collaboration of the Municipal Institute of Tourism (IMTUR) of Córdoba City Council for its help in carrying out this research. Thank you.

Conflicts of Interest: The authors declare no conflict of interest.

\section{References}

1. Adie, B.A. Franchising our heritage: The UNESCO World Heritage brand. Tour. Manag. Perspect. 2017, 24, 48-53. [CrossRef]

2. Io, M.-U. Understanding the core attractiveness of performing arts heritage to international touristas. Tour. Geogr. 2019. [CrossRef]

3. Nguyen, T.H.H.; Cheung, C. The classification of heritage visitors: A case of Hue City, Vietnam. J. Herit. Tour. 2014, 9, 35-50. [CrossRef]

4. McKercher, B. Towards a classification of cultural tourists. Int. J. Tour. Res. 2002, 4, 29-32. [CrossRef]

5. Poria, Y.; Butler, R.; Airey, D. The core of heritage tourism. Ann. Tour. Res. 2003, 30, 238-254. [CrossRef]

6. Poria, Y.; Reichel, A.; Biran, A. Heritage site management. Motivations and expectations. Ann. Tour. Res. 2006, 33, 162-178. [CrossRef]

7. Turner, L.; Ash, J. La Horda Dorada. El Turismo Internacional y la Periferia del Placer; Endymion: Madrid, Spain, 1991.

8. Correia, A.; Kozak, M.; Ferradeira, J. From tourist motivations to tourist satisfaction. Int. J. Cult. Tour. Hosp. Res. 2013, 7, 411-424. [CrossRef]

9. Tucker, H.; Carnegie, E. World heritage and the contradictions of 'universal value'. Ann. Tour. Res. 2014, 47, 63-76. [CrossRef]

10. Hassan, A.; Rahman, M. World Heritage Site as a label in branding a place. J. Cult. Herit. Manag. Sustain. Dev. 2015, 5, 210-223. [CrossRef]

11. Mariani, M.N.; Guizzardi, A. Does designation as a UNESCO World Heritage Site influence tourist evaluation of a local destination? J. Travel Res. 2019. [CrossRef]

12. Breakey, N.M. Study in of World Heritage visitors: The case of the remote Riversleigh Fossil Site. Visit. Stud. 2012, 15, 82-97. [CrossRef] 
13. Lourenço-Gomes, L.; Costa Pino, L.M.; Rebelo, J.F. Visitors' preferences for preserving the attributes of a World Heritage Site. J. Cult. Herit. 2014, 15, 64-67. [CrossRef]

14. Vong, L.T.N.; Ung, A. Exploring critical factors of Macau's Heritage tourism: What heritage tourists are looking for when visiting the city's iconic heritage site. Asia Pac. J. Tour. Res. 2012, 17, 231-245. [CrossRef]

15. Remoaldo, P.C.; Vareiro, L.; Ribeiro, J.C.; Santos, J.F. Does gender affect visiting a World Heritage Site? Visit. Stud. 2014, 17, 89-106. [CrossRef]

16. Antón, C.; Camarero, C.; Laguna-García, M. Towards a new approach of destination loyalty drivers: Satisfaction, visit intensity and tourist motivation. Curr. Issues Tour. 2017, 20, 238-260. [CrossRef]

17. Al-Tokhais, A.; Thapa, B. Management issues and challenges of UNESCO World Heritage Sites in Saudi Arabia. J. Herit. Tour. 2019. [CrossRef]

18. López-Guzmán, T.; Torres Naranjo, M.; Pérez Gálvez, J.C.; Carvache Franco, W. Segmentation and motivation of foreign tourists in world heritage sites. A case study, Quito (Ecuador). Curr. Issues Tour. 2019, 22, 1170-1189. [CrossRef]

19. Wang, Y.; Huang, S.; Kim, A.K. Toward a framework integrating authenticity and integrity in heritage tourism. J. Sustain. Tour. 2015, 23, 1468-1481. [CrossRef]

20. Ramires, A.; Brandao, F.; Sousa, A.C. Motivation-based cluster analysis of international tourists visiting a World Heritage City: The case of Porto, Portugal. J. Destin. Mark. Dev. 2018, 8, 49-60. [CrossRef]

21. Vidal González, M. Intangible heritage tourism and identity. Tour. Manag. 2008, 29, 807-810. [CrossRef]

22. Gómez Schettini, M.; Almirón, A.; González Bracco, M. La cultura como recurso turístico de las ciudades. El caso de la patrimonialización del tango en Buenos Aires, Argentina. Estudios y Perspectivas en Turismo 2011, 20, 1027-1046.

23. Prada-Trigo, J.; Pérez Gálvez, J.; López-Guzmán, T.; Pesantez, S. Tourism and motivation in cultural destinations: Towards those visitors attracted by intangible heritage. Almatourism 2016, 14, 17-37. [CrossRef]

24. González Santa Cruz, F.; López-Guzmán, T. Culture, tourism and World Heritage Sites. Tour. Manag. Perspect. 2017, 24, 111-116. [CrossRef]

25. Del Barrio, M.J.; Devesa, M.; Herrero, L.C. Evaluating intangible cultural heritage: The case of cultural festivals. City Cult. Soc. 2012, 3, 235-244. [CrossRef]

26. UNESCO-EIIHCAP. Regional Meeting. Safeguarding Intangible Heritage and Sustainable Cultural Tourism: Opportunities and Challenges; UNESCO: Paris, France, 2007.

27. Timothy, D.J.; Boyd, S.W. Heritage Tourism; Pearson Education: London, UK, 2003.

28. Di Giovine, M.A. The Heritage-Scape. UNESCO. World Heritage and Tourism; Lexington Book: Lanham, MD, USA, 2009.

29. Timothy, D.J. Cultural Heritage and Tourism; Channel View Publications: London, UK, 2011.

30. Park, H.Y. Heritage Tourism; Routledge: London, UK, 2014.

31. Poria, Y.; Reichel, A.; Cohen, R. Tourist perceptions of World Heritage Site and its designation. Tour. Manag. 2013, 35, 272-274. [CrossRef]

32. Su, M.M.; Wall, G. Chinese research on World Heritage Tourism. Asia Pac. J. Tour. Res. 2011, 16, 75-88. [CrossRef]

33. Trinh, T.T.; Ryan, C.; Cave, J. Evaluating heritage: Tourists and holiday visits to heritage sites. J. Tour. Cult. Chang. 2016, 14, 129-149. [CrossRef]

34. Muñoz-Fernández, G.; López-Guzmán, T.; López-Molina, D.; Pérez-Gálvez, J. Heritage tourism in the Andes, the case of Cuenca, Ecuador. Anatolia 2017, 29, 326-336. [CrossRef]

35. Adie, B.A.; Hall, C.M. Who visits World Heritage? A comparative analysis of three cultural sites. J. Herit. Tour. 2017, 12, 67-80. [CrossRef]

36. Saipradist, A.; Staiff, R. Crossing the cultural divide: Western visitors and interpretation at Ayutthaya World Heritage Site. Thailand. J. Herit. Tour. 2007, 2, 211-224. [CrossRef]

37. Chen, G.; Huang, S. Understanding Chinese cultural tourists: Typology and profile. J. Travel E Tour. Mark. 2018, 35, 162-177. [CrossRef]

38. Silberberg, T. Cultural tourism and business opportunities for museums and heritage sites. Tour. Manag. 1995, 16, 361-365. [CrossRef]

39. McKercher, B.; du Cros, H. Testing a cultural tourism typology. Int. J. Tour. Res. 2003, 5, 45-58. [CrossRef]

40. Park, D.B.; Yoon, Y.S. Segmentation by motivation in rural tourism: A Korean case study. Tour. Manag. 2009, 30, 99-108. [CrossRef] 
41. Prayag, G. Images as pull factors of a tourist destination: A factor-cluster segmentation analysis. Tour. Anal. 2010, 15, 213-226. [CrossRef]

42. Dolnicar, S. Tourism Management, Analysis, Behavior and Strategy; Woodside, A., Martin, D., Eds.; CABI: Cambridge, UK, 2008; pp. 129-150.

43. Dolnicar, S.; Kaiser, S.; Lazarevski, K.; Leisch, F. Biclustering: Overcoming data dimensionality problems in market segmentation. J. Travel Res. 2012, 51, 41-49. [CrossRef]

44. Prayag, G.; Hosany, S. When Middle East meets West: Understanding the motives and perceptions of young tourists from United Arab Emirates. Tour. Manag. 2014, 40, 35-45. [CrossRef]

45. Sheppard, A.G. The sequence of factor analysis and cluster analysis: Differences in segmentation and dimensionality through the use of raw and factor scores. Tour. Anal. 1996, 1, 49-57.

46. Dolnicar, S. A review of data-driven market segmentation in tourism. J. Travel \& Tour. Mark. 2002, 12, 1-22. [CrossRef]

47. Pearce, P.L. Perceived changes in holiday destinations. Ann. Tour. Res. 1982, 9, 145-164. [CrossRef]

48. Kim, A.K.; Brown, G. Understanding the relationships between perceived travel experiences, overall satisfaction, and destination loyalty. Anatolia 2012, 23, 328-347. [CrossRef]

49. Abuamoud, I.N.; Libbin, J.; Green, J.; Alrousan, R. Factors affecting the willingness of tourists to visit cultural heritage sites in Jordan. J. Herit. Tour. 2014, 9, 148-165. [CrossRef]

50. Yolal, M.; Woo, E.; Cetinel, F.; Uysal, M. Comparative research of motivations across different festival products. Int. J. Event Festiv. Manag. 2012, 3, 66-80. [CrossRef]

51. Iso-Ahola, E. Towards a social psychology theory of tourism motivation: A rejoinder. Ann. Tour. Res. 1982, 9, 256-262. [CrossRef]

52. Pearce, P.L.; Lee, U. Developing the travel career approach to tourist motivation. J. Travel Res. 2005, 43, 226-237. [CrossRef]

53. Dann, G.M. Anomie ego-enhancement and tourism. Ann. Tour. Res. 1977, 4, 184-194. [CrossRef]

54. Crompton, J.L. Motivations for pleasure vacation. Ann. Tour. Res. 1979, 6, 408-424. [CrossRef]

55. Maumbe, K.; Arbogast, D. Relationship between visitor motivations, destination evaluation and future behaviour intentions: The case of West Virginia. Tourism 2015, 63, 465-478.

56. Sato, S.; Kim, H.M.; Buning, R.J.; Harada, M. Adventure tourism motivation and destination loyalty: A comparison of decision and non-decision makers. J. Destin. Mark. E Manag. 2018, 8, 74-81. [CrossRef]

57. Vareiro, L.; Freitas Santos, J.; Remoaldo, P.C.; Cadima Ribeiro, J. Evaluating the Guimarães 2012 European capital of culture: National and international tourists' behaviors and perceptions. Event Manag. An Int. J. 2016, 20, 88-98. [CrossRef]

58. Romao, J.; Neuts, B.; Nijkamp, P.; Van Leeuwen, E. Culture, product differentiation and market segmentation: A structural analysis of the motivation and satisfaction of tourists in Amsterdam. Tour. Econ. 2015, 21, 455-474. [CrossRef]

59. Almeida-Santana, A.; Moreno-Gil, S. Understanding tourism loyalty: Horizontal vs. destination loyalty. Tour. Manag. 2018, 65, 245-255. [CrossRef]

60. Park, E.; Choi, B.-K.; Lee, T.J. The role and dimensions of authenticity in heritage tourism. Tour. Manag. 2019, 74, 99-109. [CrossRef]

61. Oliver, R.L. A cognitive model of the antecedents and consequences of satisfaction decisions. J. Mark. Res. 1980, 27, 460-469. [CrossRef]

62. Cronin, J.J.; Brady, M.K.; Hult, T.M. Assessing the effects of quality. value. and customer satisfaction on consumer behavioral intentions in service environments. J. Retail. 2000, 76, 193-218. [CrossRef]

63. Bigné,J.E.; Font, X.; Andreu, L. Marketing de Destinos Turísticos: Análisis y Estrategias de Desarrollo; Esic Editorial: Madrid, Spain, 2000.

64. Yoon, Y.; Uysal, M. An examination of the effects of motivation and satisfaction on destination loyalty: A structural model. Tour. Manag. 2005, 26, 45-56. [CrossRef]

65. Chi, C.G.Q.; Qu, H. Examining the structural relationships of destination image. tourist satisfaction and destination loyalty: An integrated approach. Tour. Manag. 2008, 29, 624-636. [CrossRef]

66. Yuksel, A.; Yuksel, F.; Bilim, Y. Destination attachment: Effects on customer satisfaction and cognitive, affective and conative loyalty. Tour. Manag. 2009, 31, 274-284. [CrossRef]

67. Lee, C.K.; Lee, Y.K.; Wicks, B. Segmentation of festival motivation by nationality and satisfaction. Tour. Manag. 2004, 25, 61-70. [CrossRef] 
68. Yuan, J.; Jang, S. The effects of quality and satisfaction on awareness and behavioral intentions: Exploring the role of a wine festival. J. Travel Res. 2008, 46, 279-288. [CrossRef]

69. Devesa, M.; Laguna, M.; Palacios, A. The role of motivation in visitor satisfaction: Empirical evidence in rural tourism. Tour. Manag. 2010, 31, 547-552. [CrossRef]

70. Finn, M.; Elliott-White, M.; Walton, M. Tourism and Leisure Research Methods: Data Collection, Analysis and Interpretation; Pearson Education: Harlow, UK, 2000.

71. Instituto Nacional de Estadística. Encuesta de Ocupación Hotelera; Servicio de Publicaciones del Instituto Nacional de Estadística: Madrid, Spain, 2019.

72. Cronbach, L.J. Coefficient Alpha and the internal structure of tests. Psychometrika 1951, 16, 297-334. [CrossRef]

73. Morales Vallejo, P.; Urosa Sanz, B.; Blanco Blanco, A. Construcción de Escalas de Actitudes Tipo Likert: Una Guía Práctica; La Muralla: Madrid, Spain, 2003.

74. Hair, J.F.; Black, W.C.; Babin, H.J.; Anderson, R.E. Multivariate Data Analysis; Prentice Hall: Upper Saddle River, NJ, USA, 2010.

75. Kruskal, W.H.; Wallis, W.A. Use of ranks in one-criterion variance analysis. J. Am. Stat. Assoc. 1952, 47, 583-621. [CrossRef]

76. Mann, H.B.; Whitney, D.R. On a test of whether one of two random variables is stochastically larger than the other. Ann. Math. Stat. 1947, 18, 50-60. [CrossRef]

77. Urry, J. The Tourist Gaze: Leisure and Travel in Contemporary Societies; Sage: London, UK, 1990.

78. Bruner, E.M. Tourism in Ghana: The representation of slavery and the return of the Black diaspora. Am. Anthropol. 1996, 98, 290-304. [CrossRef]

79. Cheung, S.C.H. The meanings of a heritage trail in Hong Kong. Ann. Tour. Res. 1996, 26, 570-588. [CrossRef]

(C) 2020 by the authors. Licensee MDPI, Basel, Switzerland. This article is an open access article distributed under the terms and conditions of the Creative Commons Attribution (CC BY) license (http://creativecommons.org/licenses/by/4.0/). 